\title{
Sarcasm in Arms and the Man
}

\begin{abstract}
Abdalatif Ali
Abstract: George Bernard Shaw in his literary work covered varied topics that touch the lives of the British community socially and politically, he treated many issues concerning the social life with his dramatic views and stand against the government calling for the rights of his folk verbally and dramatically. George Bernard Shaw enriched English literature with his masterpieces, entertain the audience with his plays in. Arms and The Man, he explores the themes of the play in a very sarcastic and funny way, and at the same time send a message to the solders at that time, through his men characters of a play, also he explained his views of love contradicting the traditions and customs of the society, when Sergius (master) engaged to Louka the servant, this paper shed a light on the sarcasm and irony of Bernard Shaw. The playwright used his creativity to produce a very interesting play full of sarcasm and irony, Petcoff despised his wife when he saw the underclothes spread on the bushes among visitors, his wife scorns him when he shouted for the servant, she told him that civilized people didn't shout for their servants. The servants scorn each other's Nicola told Louka that, he taught her how to trim her nails, she said to Nilcola that you sell your manhood for money and I was not. Raina called the fugitive the chocolate cream solder, because he take chocolate in his pockets in the battle field instead of ammunition
\end{abstract}

Keywords: 1- sarcasm (noun) The use of words or expressions to mean the opposite of what they say. people use sarcasm to criticized other people or to make them look silly

\section{Introduction}

Literature was a mirror of life, regardless of its genre .Drama was a matter of imitating real life the theatre repressed the location and the players are the people in life every audience will find an action that happened to him or her in real life .Anthony Burgess said that "Drama is the most natural of the arts ,being based on one of the most fundamental of the human and animals faculties, the faculty of imitation it is through imitation that animals learn to fight ,climb ,hunt .It is through imitation that children learn to talk to perform great number complicated human functions .This imitative faculty, or as we call it memetic faculty, makes us all actors almost from the cradle "English Literature .P44

George Bernard Shaw was born July 26, 1856, in Dublin, Ireland. In 1876 he moved to London, where he wrote regularly but struggled financially. In 1895, he became a theater critic for the Saturday Review and began writing plays of his own. His play Pygmalion was later made into a film twice, and the screenplay he wrote for the first version of it won an Oscar. During his lifetime, he wrote more than 60 plays and won many other awards, among them the Nobel Prize.

Among these plays was his masterpiece Arms and the man, in which he explored the life of the Bulgarian and Serbian societies in an interesting play, he mirrored this life to his Elizabethan audience during the 18 centuy. Bernard Show displayed a great genius in creating his characters mainly Petkoff and his wife Catharine.

Bernard Shaw represented sarcasm of his play through dramatic personate each character resembles a Peron in real life e.g. Serge's represent the foolishness of solders, Catharine represents the old women in England at the time of Shaw. Pickoff represents the weakness of men besides their wives

After reading the play I have decided to write about his sarcasm which appeared among the characters. from the starting point of the play up to the end. the paper followed the sarcastic characters one by one with comments on the quotations. The reader of the play from the first look can feel the sarcasm of the writer, because it is so obvious.

\section{Sarcasm in Act One}

The scene took place in Rain's bedroom, during the Night of November in the year 1885, she was entertaining herself looking at the Balkan mountains, and thinking about her future husband Sergiu's, who was at the battlefield fighting for his country.

She thinks that Sergiu's did the cleverest thing which ever done, because he headed A cavalry charge and face the Russian armies with their machine guns, Bernard show revealed the ignorance of Sergiu's by the art of war, how can he fight his enemies with swords and they used guns !!!!!!!!

While Rain was reading a book so as to sleep, suddenly she listened to a sound of shouting outside, she saw a man climbing the balcony to her bedroom. She looked at the man who was so dirty and warn her not to shout, she becomes quiet after this threatening then, they talked for a while the following is part of their conversation

From this dialogue, Raina despises the man for taking her clock to save himself, because she couldn't receive any one without underclothes.

Bernard show viewed solders as foolish people, while Raina was hiding a man in her room a Russian officer came to search for him, the officer didn't saw the man or noticed his pistol on the ottoman. although Louka a female servant saw the man, but she didn't speak satisfies herself with just purses her lips .. as if Bernard Show said to the officer the servant was clever than you.

\section{Volume 6 Issue 12, December 2017}




\section{International Journal of Science and Research (IJSR) \\ ISSN (Online): 2319-7064 \\ Index Copernicus Value (2016): 79.57 | Impact Factor (2015): 6.391}

From the above-mentioned Bernard Show used the character of the man to sardonic the Bulgarian society in the battle field and in their houses

Raina wry the man when she said: "take your pistol to protect yourself a against me" Mr. Blunchli (grinning wearily at the sarcasm as he takes the pistol). she also despised him, when she knew that he took chocolate instead of ammunition Do you fill your pockets with chocolate like a schoolchild - even in the battle?

Raina asked the man to leave her room, when he went to the window to climb down the waterpipe. she stopped him, not to save his life, but to show him that they were noble and rich people.

Inevitably he will ask about Petkoff. She told him that we are the richest family in Bulgaria and well known in all over the country, you never heard about us, he said no, she replied stop pretending.

I toll you these things to shew you that you are not in the house of ignorant country folk who would kill you the moment they saw your Serbian uniform, but among civilized people. We go to Bucharest every year for the opera season; and I have spent a whole month in Vienna.

Bernard Shaw makes her so primitive in this situation. How can a man from Switzerland know her family in Bulgaria? as if her family was a national one and everyone in the universe should know them.

I think he wants to tell his audience that there is a sort of women consider to be (show women) this character belongs to this type. for Blenchli he scorned her inside because these things (mentioned by Raina) are so common for him and she need not mentioned them, but for her these belongings refer to a great luxury.

\section{Sarcasm in Act Two}

The act took place in the garden o Major Petcoff house it is a breakfast time.

The task of the servant is to serve his or her master without complaining, but to scorn the master was something strange in the conversation between Nicola and Louka . Bernard Shaw revealed how a servant defies her Mistress.

Nicola: Louka mend your manner.

Louka: I do defy her, I will have defeated her. What do I care for her? she insists to defy her Mistress because she knows a secret about her, when Raina hide the fugitive in her bedroom, she wants to use this secret against Raina .

When petcoff returns from war. Kathrine asked him a question she despites him verbally.

Bernard Shaw's sarcasm appeared clearly in the above quotation they go on with their conversation.
"Catharine said: you are barbarian at heart pual I hope you behave yourself before all those Russain officers" p20.

Petcoff I did my best took care to let them know that we have a library "

His answer was a great sarcasm, they despised each other's the man wants to tell her that she was so primitive and she intend to show him that he was not civilized.

Catharine ...But you don't tell them that we have a library electric bell in it. I have had one put up.

Petcoff What electric bell. Catharine, you touch a bottom something tinkles in the kitchen and Nicloa comes up.

Petkoff why not shot on him. Catharine civilized people never shout for their servants. "Ibid

When he feels that she defies him he looked at the bushes in the garden and Petkof said: well. I will tell you something I have learned too civilized people did not hung out their washing to dry when visitors can see it .

Bernard Shaw sarcasms men, because the power was with their wives, not only he despised the men, but also the leaders mainly in the war, this clear when Sergius said

He confessed that the Swiss cheated them, although he was a solder and they are leaders, because they are so simple men, and they are not intelligent so as to think deeply and get out with a decision

Sergius was not satisfy by such a thing he said to petcoff we were two children in the hands of consummate solder, major two innocent little children "p24

Bernard Shaw despised the men in addition to the above when the two men should sit to think about how they send three regiments to Philipopliss Catharine prevented Sergius and said to Petcoff "Can't you spare Segius for a few moments .....I can help you " 25 .

It was so strange how can a house wife helped the leader of the country 's army.

Catharine skedRaina about the length of the time that a man spends in her bedroom, she said I don't know. Then her mother said what Sergius do if he knows that. Raina did not care about him and she scorned her mother saying " I know Sergius is your pet. I sometimes wish you could marry him instead of me, you would just suit him 'p29

\section{Sarcasm in Act Three}

This Act took place in the in the library of Petcoff's house after lunch. Captain Blunchli finished the work of sending the three regiments and through the papers to Sergius to sign them. He told Petcoff to give the solders strict orders so as not to delay in the way. In this situation Bernard Shaw used his deep imagination to get out with this sarcasm.

Volume 6 Issue 12, December 2017 


\section{International Journal of Science and Research (IJSR) \\ ISSN (Online): 2319-7064}

Index Copernicus Value (2016): 79.57 | Impact Factor (2015): 6.391

What sort of leader was this man II Blunchli was astonished he said: " What country, they make canons out of cheery trees and the officers send for their wives to keep decline " Ibid

Captain Blunchli took Raina seriously, he told her that you are not straight forward, because she tells lies she confessed and said "I suppose that you have found me out, you despise me "

Even the servants despised each other's when Nicola talked to Louka about money given to him she said:

Nicola did not listen to such a scorn silently he in return he said to her" I f any luck comes to you, it was I that makes a woman of you ... at last he said: "Who was it made you give up wearing a couple of pounds of two black hair on your head and reddening your lips and cheeks I taught you to trim your nails "Ibid.

As he wants to tell her that she was primitive and backwards before she knew him and he makes her a civilized girl.

Sarcasm reach its Peak when a maid despised her master. Louka talked to Sergius about the Swiss she told him that the Swiss will marry Raina, she will not harry you.

Louka " Aman worth ten of you, then you can come to me and I will refuse, you are not good enough for me "p45 .

The conversation between Sergius and Blunchli when he escaped and Raina received him in her room, Blunchli scorn Sergius deeply when he said: "Yes you blockhead, she received me with the pistol on her head "p47.

When they finished their conversation, Raina comes in and listen to the last part of their speech, she was engaged to Sergius, but she saw him holding Louka in his arms. when he called Blunchli his rival, she told him that Blunchli was not your rival, but your rival was Nicola the servant Louka was engaged to him and then said: " A Shocking sacrifice isn't it ,such beauty such intelligent ... wasted in a middle class servant man " p49

\section{Conclusion}

The paper cast a light on Bernard Shaw's sarcasm in his masterpiece Arms and The Man. He used his talent to explain the traditions and customs of the Bulgarian society, represented by major Petcoff's family and their servants at that time, he was successful in producing his characters and let them speaks about their roles sarcastically and ironically.

The plot was suspended the reader and the ironic situations gave the play especial flavor. Bernard Shaw explored the themes war and love in the society among his characters.

Catharine thinks that she was so civilized, because she had a bell. Her husband did not believe in such civilization and proved his idea, when he said civilized people didn't hung their clothes among visitors.

Raina believed in her love to Surgius and changed her mind instantly when she found Mr. Blunchli.

Sergius loved Louka the servant instead of the mistress. The most stable character was Mr. Blunchli at the beginning a professional solder and at the end a business man.

In conclusion Bernard Shaw explained sarcasm. irony and sardonic in a unique language, it make the play more enjoyable and excellent.

\section{References}

[1] Anthony Burgess. English Literature. published Longman Group UK. limited Longman House BURNT Mill .Harlow .Essex. CM202JE.England. Produced through Longman.Malaysia.CL.21 EDITION 1995

[2] http://www.biography.com/people/george-bernard-shaw9480925

[3] https://en.oxforddictionaries.com/definition/sardonic.

[4] Arms And The Man .George Bernard Shaw .Published by Yurok Press 2002.

[5] Oxford word power .Oxford University Press Second Edition . 2006 